\title{
The Impact of Different Production Systems on the Content of Lycopene in Tomato Fruits
}

\author{
Omer Kurtović ${ }^{1}$, Aleksandra Govedarica-Lučić ${ }^{* 2}$, Goran Perković ${ }^{2}$ Alma Rahimićc ${ }^{3 \dagger}$ \\ ${ }^{1}$ Federal Office for Agriculture, Bosnia and Herzegovina \\ ${ }^{2}$ Faculty of Agriculture, University of East Sarajevo, Bosnia and Herzegovina \\ ${ }^{3}$ Agro-mediterannean faculty, University of "Dzemal Bijedic", Mostar, Bosnia and Herzegovina
}

*Corresponding author: sandraklepic@yahoo.com

\begin{abstract}
Tomato (Lycopersicon esculentum Mill.) is one of the most widespread vegetable crops for multiple uses in the diet of the human population. Tomato products and tomatoes are an important source of vitamin C, copper and iron, and contain significant amounts of B vitamins, and minerals such as potassium, sodium, magnesium and calcium. However, tomato lycopene seems particularly precious, active substances from the carotenoid family that plays an important role in the defense of the health of human organism.In the fruits of tomatoes lycopene is dominant carotenoid, and besides him there are also smaller facilities $\alpha$-carotene, $\beta$-carotene, $\gamma$-carotene, phytoene, fitofluena, neurosporena and lutein. The content of lycopene in tomatoes is largely dependent on the different agro-ecological conditions, primarily temperature, solar radiation and humidity. It is clear that the variety, stage of maturity, different environmental conditions and production methods affect the chemical and physical characteristics of agricultural products. Bearing in mind the nutritional and halth importance of representation of tomatoes in the diet and the area in which this kind of vegetable products, the objective of this research is to examine the impact of different production systems (organic, integrated and conventional) on the synthesis and content of lycopene in tomatoes.All production systems include the established methodology that is used for the production of tomatoes in open field (block system). Within each type of production were included tomato hybrids Matias F1 and Sakura F1. The highest content of lycopene was recorded in the integrated production $(6.05 \mathrm{mg} / 100 \mathrm{~g})$, and the lowestin conventional $(5.88 \mathrm{mg} / 100 \mathrm{~g})$. The highest contentof lycopenehad ahybridSakuraF1from6.34to6.56 $(\mathrm{mg} / 100 \mathrm{~g})$ depending on the mode of production
\end{abstract}

Key words: tomato,lycopene,system of farming.

\section{INTRODUCTION}

Tomato is a very popular vegetable and it is worldwide used every day. In human nutrition, tomato is a rich source of lycopene, $\beta$ - carotene, $\alpha$ - tocopherol, phenolic components, the necessary minerals, primarily potassium and carboxylic acids including ascorbic, citric, maleic, fumaric and oxalic.

Some of these compounds are characterized by the tomato antioxydation(Gastélum-Barrios et al., 2011). Tomatoes and tomato products are the most important source of lycopene in which he was dominant carotenoid (Fraser et al., 2001; Shi andMaguer, 2000.). In addition to the wealth of sources of vitamin $\mathrm{C}, \mathrm{Cu}$ and $\mathrm{Fe}$ also contains significant amounts of $\mathrm{B}$ vitamins and mineral substances such as $\mathrm{K}, \mathrm{Na}, \mathrm{Mg}$ and $\mathrm{Ca}$.

Lycopene is particularly valuable active substances from the carotenoid family that plays an important role in preventing the development of tumors of prostate, digestive system, breast, lung, and plays an important role in protecting against

Paper presented at the 6th International Scientific Agricultural Symposium "AGROSYM 2015

Note: Authorship Form signed online. 
heart disease and blood vessels.Lycopene , the pigment responsible for the red color of tomatoes, causing a huge interest because of their biological and physical and chemical properties, especially the antioxidant effects related, inter alia, to reducing the damage proteins, lipids and other cell contents. Among other carotenes, lycopene is one of the contents of food with potential functional effects. The antioxidant activity of lycopene and other carotenoids reflected stabilization of reactive oxygen species and free radical scavenging ability(Bramley, 2000; Burton and Ingold, 1984.).Because of the nutritional and health importance representation of tomatoes in the diet and the area in which this kind of vegetable products, the objective of this research is to examine the impact of different production systems (organic, integrated and conventional) on the synthesis and content of lycopene in tomatoes. The content of lycopene in fresh tomato fruit depends on the system of cultivation (conventional, integrated, organic production), varieties, stage of maturity and different environmental conditions in which the fruit maturing and usually ranges from 3 to $5 \mathrm{mg} / 100 \mathrm{~g}$ (Bramley, 2000).

\section{MATERIALS AND METHODS}

A two-year study was conducted during 2012- 2013 in research station "Butmir" Sarajevo (Bosnia and Herzegovina) at an altitude of $550 \mathrm{~m}$. The experiment was set up separately (isolated) for organic, integrated and conventional production. All production systems include the established methodology that is used for the production of tomatoes in open field (block system). Within each type of production were included tomato hybrids Matias F1 and Sakura F1.

The experiment was set in a randomized design with five repetitions. The main plot size was $4.2 \mathrm{~m}^{2}$. Tomato plants were planted in two-row strips, where in the spacing between the rows was $80 \mathrm{~cm}$, distance in the row $50 \mathrm{~cm}$, the distance between the strip $1 \mathrm{~m}$ achieving a makes plant spacing of 2.85 plants $/ \mathrm{m}^{2}$.The concentration of lycopene in tomato samples was determined by spectrophotometric method in the

laboratory of the Federal Institute for Agriculture Sarajevo. Statistical analysis of the results was determined by analysis of variance and LSD test. The data obtained in the research are presented in tables and graphs.

\section{RESULTS AND DISCUSSION}

Climatic and soil conditions

The results of chemical analyzes of soil show that it is a slightly acidic soil reaction. The content of total $\mathrm{N}$ is 0.40 $\%$, which indicates that the land is very rich with nitrogen. A sample of soil containing moderate amounts of phosphorus $\mathrm{P}_{2} \mathrm{O}_{5}(14,50 / 100 \mathrm{~g}$ soil $)$ and potassium $\mathrm{K}_{2} \mathrm{O}(16,20 \mathrm{mg} / 100 \mathrm{~g})$. The humus content in\% is 1.90 , which indicates that the land is low humus.

Mean monthly temperature in research station "Butmir" in 2012 were highest in July $23.5\left({ }^{\circ} \mathrm{C}\right)$, and the lowest in February $-4.7\left({ }^{\circ} \mathrm{C}\right)$. During 2013, average monthly temperatures in Butmir were recorded during August $21.7\left({ }^{\circ} \mathrm{C}\right)$ and the lowest in the month of January $2.0\left({ }^{\circ} \mathrm{C}\right)$.

Agricultural production fallout among meteorological elements has a dominant influence. The highest amount of rainfall in Butmir in 2012 was in May (144.9) and the lowest in March (13.0). In 2013, at the site of Butmir greatest amount of precipitation was in May (136.0), while the lowest was in July (27.3). 
Table 1.Mean monthly air temperature

\begin{tabular}{llllllllll}
$\underbrace{\text { parameter }}_{\text {month }}$ & I & II & III & IV & V & VI & VII & VIII & IX \\
\hline $\begin{array}{c}\text { air temperature } \\
\text { 2012.year }\end{array}$ & $-1,2$ & $-4,7$ & 6,9 & 10,3 & 13,7 & 22,0 & 23,5 & 23,2 & 18,1 \\
$\begin{array}{c}\text { air temperature }\left({ }^{\circ} \mathrm{C}\right) \\
\text { 2013.year }\end{array}$ & 2,0 & 2,3 & 5,3 & 12,4 & 15,2 & 18,3 & 20,4 & 21,7 & 15,4 \\
\hline
\end{tabular}

Source: Weather Stations Butmir

Table 2.Total of rainfall

content of lycopene in hybrid Matias in

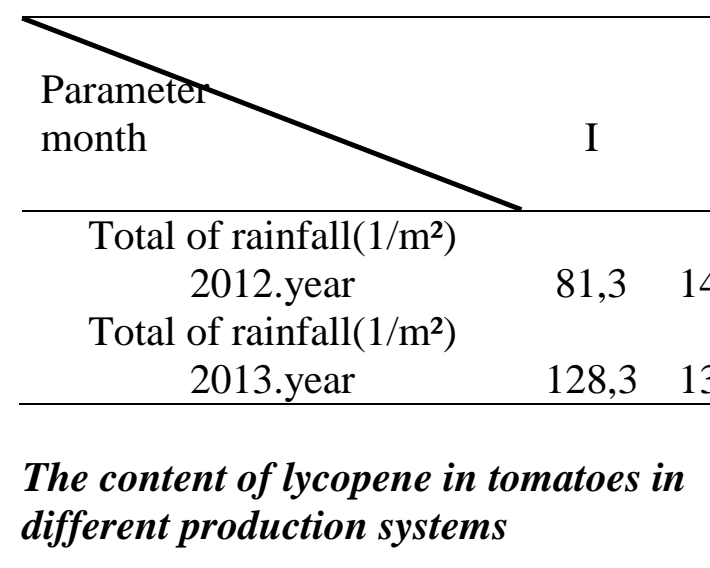

The concentration of lycopene in tomato samples was determined by spectrophotometric methods in the laboratory of the Federal Institute for Agriculture Sarajevo.

In most studies, after extraction of lycopene from a sample of the appropriate solution, spectrophotometric measurements are performed at 460 to $470 \mathrm{~nm}$. The concentration of lycopene was determined by a spectrophotometer and a calibration diagram chart (Shi and Maguer, 2000; Mencarelli and Saltveit, 1988; Tan and Soderstrom, 1988).

The content of lycopene in 2012. in different production systems (organic, integrated and conventional) in a hybrid Matias had different values. The highest

\section{(1)

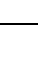

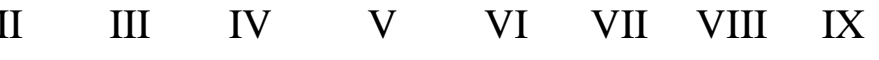


Tab. 3. The content of lycopene $\mathrm{mg} / 100 \mathrm{~g}$

\begin{tabular}{|c|c|c|c|c|}
\hline \multirow{2}{*}{ Variant production } & \multicolumn{2}{|c|}{ 2012.year } & \multicolumn{2}{|c|}{ 2013.year } \\
\hline & Matias F1 & Sakura F1 & Matias F1 & Sakura F1 \\
\hline organic & 5,40 & 6,28 & 5,57 & 6,54 \\
\hline integral & 5,41 & 6,30 & 5,70 & 6,82 \\
\hline conventional & 5,06 & 6,32 & 5,78 & 6,37 \\
\hline LSD 5\% & \multicolumn{2}{|c|}{0,09} & \multicolumn{2}{|c|}{0,06} \\
\hline LSD1\% & \multicolumn{2}{|c|}{0,13} & \multicolumn{2}{|c|}{0,30} \\
\hline
\end{tabular}

In the second year, the highest content of lycopene in hybridMatias was in conventional $(5.78 \mathrm{mg} / 100 \mathrm{~g})$, then the integral $(5.70 \mathrm{mg} / 100 \mathrm{~g})$ and organic production (5.57 $\mathrm{mg} / 100 \mathrm{~g})$. Hybrid Sakura highest content of lycopene was in the integral $(6.82 \mathrm{mg} / 100 \mathrm{~g})$, then the organic $(6.54 \mathrm{mg} / 100 \mathrm{~g})$ and conventional production $(6,37 \mathrm{mg} / 100 \mathrm{~g}$ ). Significantly statistically differences have been revealed in the integral over conventional production and statistically significant differences in relation to organic production. The results of this study are consistent with the research (Mitchel et al, 2007; Bramley, 2000).

Table.4. The two-year average content of lycopene $(\mathrm{mg} / 100 \mathrm{~g})$

\begin{tabular}{|c|c|c|c|}
\hline \multirow[t]{2}{*}{ Variant production } & \multicolumn{2}{|c|}{ Hybrids } & \multirow[t]{2}{*}{ Average } \\
\hline & Matias F1 & Sakura F1 & \\
\hline organic & 5,48 & 6,41 & 5,94 \\
\hline integral & 5,55 & 6,56 & 6,05 \\
\hline conventional & 5,42 & 6,34 & 5,88 \\
\hline Average & 5,48 & 6,43 & 5,95 \\
\hline
\end{tabular}

Looking at the long term average lycopene content can be seen to have been the largest in the integrated production $(6.05 \mathrm{mg} / 100 \mathrm{~g})$, and the lowes in conventional $(5.88 \mathrm{mg} / 100 \mathrm{~g})$. The highest content of lycopene had a hybrid Sakura F1 from 6.34 to 6.56 $\mathrm{mg} / 100 \mathrm{~g}$,depending on the mode of production.

\section{CONCLUSION}

Based on research on the impact of cultivation (organic, conventional and integrated production system) on the yield and quality of different hybrids tomato (Matias and Sakura) under conditions of moderate continental climate ( Butmir - Sarajevo ) was concluded:

The content of lycopene in the year 2012 . in different production systems (organic, integrated and conventional) in a hybrid Matias had different values. The highest content of lycopene in hybrid Matias was in integral $(5.41 \mathrm{mg} / 100 \mathrm{~g})$, then the 
organic $(5.40 \mathrm{mg} / 100 \mathrm{~g} \quad)$ and conventional production $(5.06 \mathrm{mg} / 100 \mathrm{~g})$ .The highest content of lycopene in hybrid Matias in the year 2013. was in the conventional $(5.78 \mathrm{mg} / 100 \mathrm{~g})$, then the integral $(5.70 \mathrm{mg} / 100 \mathrm{~g})$ and organic production $(5.57 \mathrm{mg} / 100 \mathrm{~g})$.

The highest content of lycopene in hybrid Sakura in the year 2012. was in the conventional system $(6.32 \mathrm{mg} / 100 \mathrm{~g})$, then the integral $(6.30 \mathrm{mg} / 100 \mathrm{~g})$ and organic production $(6.28 \mathrm{mg} / 100 \mathrm{~g})$. Hybrid Sakura in 2013, the highest content of lycopene was in the system of integral $(6.82 \mathrm{mg} / 100 \mathrm{~g})$, then the organic $(6.54 \mathrm{mg} / 100 \mathrm{~g})$ and conventional production $(6.29 \mathrm{mg} / 100 \mathrm{~g})$.

\section{ACKNOWLEDGEMENTS}

Authors would like to thank all those who have directly or indirectly supported them in the preparation of this paper mainly by providing them generously with the required information.

\section{REFERENCES}

Bramley, P. M. 2000. Is lycopene beneficial to human health? Phytochem, 54: 233 -236.

Burton, G. W. and Ingold, K. U. 1984. $\beta$ carotene: an unusual type of lipid antioxidant. Science, 224: 569-573.

Dumas, Y., M. Dadomo, G. Di Lucca, and Grolier, P. 2003. Effects of environmental fac-tors and agricultural techniques on antioxidant content of tomatoes. $J$. Sci. Food Agr. 83: 369-382.

Fraser, P. D., Bramley, P., Seymour, G.B. 2001. Effect of the Cnr mutation on carotenoid formation during tomato fruit ripening. Phytochemistry, 58: 75-79.

Gastélum-Barrios, A., Bórquez-López, R. A., Rico-García, E., Toledano-Ayala, M. and Soto-Zarazúa, G. M. 2011. Tomato quality evaluation with image processing: A review. African Journal of Agricultural Research, 6. 3333-3339.

Kapoulas, N., Ilić, Z., Đurovka, M., Trajković, R. and Milenković, L. 2011) Effect of organic and conventional production practices on nutritional value and antioxidant activity of tomatoes. African Journal of Biotechnology, 10: 15938-15945.

Mencarelli, F. and M.E. Saltveit, Jr. 1988. Rip-ening of mature-green tomato fruit slices. J.Amer. Soc. Hort. Sci. 113: 742-745.

Mitchell, A. E, Hong, Y. J. , Koh, E., Barrett, D. M., Bryant, D. E., Denison, R. F. and Kaffka, S. 2007. Ten- of the influence of organic and conventional crop management practices on the content of flavonoids in tomatoes. Agric Food Chem., 55: 6154.

Shi, J., and Le Maguer, M. 2000. Lycopene in tomatoes: chemical and physical propoerties affected by food processing. Crit. Rev. Biotechnol., 20: 293-334.

Tan, B., and Soderstrom, D. N. (1988): Qualitative aspects of UV-VIS spectrophotometry of carotene and lycopene. Journal of Chemical Education, 22: 21-31. 